\title{
Changes in Bacterial Populations in Wyoming Mountain Streams After 10 Years
}

\author{
MICHAEL R. HUSSEY, QUENTIN D. SKINNER, AND JOHN C. ADAMS
}

\section{Abstract}

Streams of mountain watersheds in Wyoming were monitored to compare water quality data collected during 1971-72 with data collected during 1982. After 10 years there was little change in: (1) total coliforms, (2) fecal coliforms, (3) fecal streptococci, (4) plate counts at $35^{\circ} \mathrm{C}$, (5) total heterotrophic aerobic bacteria, (6) denitrifying bacteria, and (7) those organisms capable of reducing sulfate. Grazing management, recreation activities, and wildlife use of the watershed studied seem to be contributing a constant bacterial load to streams sampled by year and month during summer.

Users of watersheds may cause changes in water quality. For example, cattle grazing has been shown to increase fecal indicator organism densities in nearby waters (Buckhouse and Gifford 1976, Jahn et al. 1978, Stephenson and Street 1978, Doran and Linn 1979, Jawson et al. 1982, Stephenson and Rychert 1982). Recreational activities have been reported to decrease indicator organism densities in some streams, perhaps by causing wildlife to leave their habitat (Stuart et al. 1971; Skinner ct al. 1974a, 1974b; Varness et al. 1978). Gary (1982) found that recreational use of a campground equipped with modern sanitation facilities did not significantly affect the densities of indicator bacteria in surface waters, whereas Skinner and Adams (1977) were able to show an increase in numbers below a ski area during winter months. These higher numbers, however, decreased to base levels during spring snowmelt. Other investigators have shown increased stream flow from snowmelt or precipitation events raised the numbers of organisms in water in various drainage basins (Walter and Bottman 1967, Stuart et al. 1971, Stuart et al. 1976, Varness et al. 1978, Stephenson and Street 1978, Kay and McDonald 1980, McDonald and Kay 1981, Erickson et al. 1982, Gannon et al. 1983).

Seasonal fluctuations of indicator organism densities indicate that higher numbers may be found during the summer months (VanDonsel et al. 1967, Skinner et al. 1974b, Hendry and Leggatt 1982 ) in both streams and lakes. These fluctuations in bacterial numbers may be due to settling of indicator organisms from surface waters to bottom sediments (Kay and McDonald 1980, Gannon et al. 1983, Skinner et al. 1984). Examples of indicator organisms more numerous in sediments than in overlying waters have been documented by Hendricks (1971), Van Donsel and Geldreich (1971), Matson et al. (1978) and Skinner et al. (1984). Organisms in sediments may be resuspended by various precipitation events causing flushing flows, recreational activities, and hoof action from wildlife and livestock (Stephenson and Street 1982). Indicator bacteria in surface water and sediment have been reported to survive and grow (Hendricks and Morrison 1967). Research documenting change in bacterial populations found in stream water originating from mountain watersheds subjected to multiple user pressure with intervals of years between sampling is lacking. This study was undertaken to document changes in 7 bacterial populations in mountain streams after 10 years while management practices and user activities remained generally unchanged.

\footnotetext{
Authors are graduate student, professor range management, and professor microbiology/biochemistry, University of Wyoming, Laramie 82071 .

Published as Journal Article JA 1343 of the Wyoming Agriculture Experiment Station.

This work was funded by the Office of Water Policy, United States Department of the Interior. Annual Cooperative Program Fiscal Year 1983. Contract G879 Project CT375407 through the Wyoming Water Research Center, University of Wyoming, Laramie.

Manuscript accepted 4 November 1985.
}

\section{Materials and Methods}

Evaluation of bacterial water quality trends after 10 years were accomplished by collecting grab samples from the same streams and sites located within the Nash Fork Hydrologic Observatory. The observatory is located approximately $53 \mathrm{~km}$ west of Laramie, Wyoming and is described by Skinner et al. 1974a and 1974b.

Total coliforms (TC), fecal coliforms (FC), fecal streptococci (FS), and standard plant counts (PCA) at $35^{\circ} \mathrm{C}$ were enumerated following methods described by Skinner et al. (1974b). Total viable bacterial counts (HEN), sulfate-reducing bacteria (SULFR), and denitrifying bacteria (DEN), were enumerated as previously described by Skinner et al. (1974a).

One-way analysis of variance (ANOVA) was used to compare means from each site for each month by year for each bacterial population enumerated, water temperature, and flow rate. Significant means were separated using Duncan's new multiple range test at the $95 \%$ confidence level (Steel and Torrie 1960).

Data from 1971, 1972, and 1982 were combined and one-way ANOVA was performed to determine significant contrasts between (1) months for each test at each site, and (2) differences between sites for each test during each month.

\section{Results and Discussion}

Presented in Table 1 are the results of comparing 3 years of data for the month of July. July was chosen as being representative of the 4 months that were studied. Statistically significant differences did occur at different sites during different years; however, no distinct trends were observed. For example, the total coliforms were significantly more numerous in 1972 than in 1971 or 1982 at sample site 5 and the fecal coliforms were less numerous in 1971 at site 4 than they were in 1972 or 1982 . Thus, it appeared that the numbers of the bacterial indicators of health hazards in these waters could most likely be explained by unidentified pollution events regardless of the year. The denitrifying bacteria, the sulfate reducing bacteria, and the total bacterial count as determined on modified Henrici's agar were not statistically more numerous at any site in 1982 when compared to 1971 or 1972 . This information suggests that the natural flora of these waters has not changed over the years.

\section{Summary and Conclusions}

Bacteriological water quality in the streams of the Nash Fork Hydrologic Observatory has not changed much after 10 years. Grazing management, recreation activities, and wildlife use of this drainage basin seem to be contributing a constant bacterial load to streams sampled as no evident increases in fecal indicator organisms were noted after 10 years.

\section{Literature Cited}

Buckhouse, J.C., and G.F. Gifford. 1976. Water quality implications of cattle grazing on a semi-arid watershed in southeastern Utah, J. Range Manage. 29:109-113.

Doran, J.W., and D.M. Linn. 1979. Bacteriological quality of runoff water from pastureland. Appl. Environ. Microbiol. 37:985-991

Erickson, D.C., H.L. Gary, S.M. Morrison, and G. Sanford. 1982. Pollution indicator bacteria in stream and potable water supply of the Manitou Experimental Forest, Colorado. USFS. Research Note-RM:451-1-7. 
Table 1. Comparison of bacterial counts between years for July. Nash Fork Hydrologic Observatory.

\begin{tabular}{|c|c|c|c|c|c|c|c|c|c|c|c|c|}
\hline Site & Year & $\begin{array}{l}\log \\
\frac{T C}{100 \mathrm{ml}}\end{array}$ & $\begin{array}{l}\log \\
\frac{\mathrm{PCA}}{100 \mathrm{ml}}\end{array}$ & $\frac{\log }{\mathrm{HEN}}$ & $\begin{array}{l}\log \\
\frac{\mathrm{FC}}{100 \mathrm{ml}}\end{array}$ & $\begin{array}{l}\log \\
\frac{\mathrm{DEN}}{100 \mathrm{ml}}\end{array}$ & $\begin{array}{l}\log \\
\mathrm{FS} \\
100 \mathrm{ml}\end{array}$ & $\begin{array}{l}\log \\
\frac{\text { SULFR }}{100 \mathrm{ml}}\end{array}$ & $\begin{array}{l}\mathrm{FC} / \mathrm{FS} \\
\text { Ratio } \\
100 \mathrm{ml}\end{array}$ & $\begin{array}{l}\text { Sample } \\
\text { Size }\end{array}$ & $\begin{array}{l}\text { Stream } \\
\text { flow L } \\
\text { second }\end{array}$ & $\begin{array}{l}\text { Water } \\
\text { Temp } \\
\circ \mathrm{C}\end{array}$ \\
\hline 2 & $\begin{array}{l}1971 \\
1972 \\
1982\end{array}$ & $\begin{array}{l}0.56 \\
1.44 \\
0.62\end{array}$ & $\begin{array}{l}3.45 \mathrm{ab} \\
3.66 \mathrm{~b} \\
2.38 \mathrm{a}\end{array}$ & $\begin{array}{l}6.17 \\
6.32 \\
6.21\end{array}$ & $\begin{array}{l}0.30 \\
0.58 \\
0.33\end{array}$ & $\begin{array}{l}3.45 \\
2.63 \\
2.10\end{array}$ & $\begin{array}{l}0.22 \\
1.20 \\
0.72\end{array}$ & $\begin{array}{l}3.07 \\
2.22 \\
2.63\end{array}$ & $\begin{array}{l}0.825 \\
0.358 \\
0.431\end{array}$ & $\begin{array}{l}3 \\
5 \\
4\end{array}$ & $\begin{array}{r}1075.4 a \\
309.6 b \\
789.0 c\end{array}$ & $\begin{array}{r}6.83 \\
10.40 \\
6.75\end{array}$ \\
\hline 3 & $\begin{array}{l}1971 \\
1972 \\
1982\end{array}$ & $\begin{array}{l}0.73 \\
1.24 \\
0.88\end{array}$ & $\begin{array}{l}3.83 \mathrm{a} \\
3.60 \mathrm{~b} \\
2.10 \mathrm{c}\end{array}$ & $\begin{array}{l}6.09 \\
6.50 \\
5.98\end{array}$ & $\begin{array}{l}0.22 \mathrm{a} \\
0.35 \mathrm{ab} \\
0.66 \mathrm{~b}\end{array}$ & $\begin{array}{l}2.70 \\
1.52 \\
2.94\end{array}$ & $\begin{array}{l}0.56 \\
1.23 \\
0.48\end{array}$ & $\begin{array}{l}2.87 \\
2.39 \\
1.78\end{array}$ & $\begin{array}{l}0.187 \\
0.093 \\
2.500 \mathrm{a}\end{array}$ & $\begin{array}{l}3 \\
5 \\
4\end{array}$ & $\begin{array}{l}820.7 \\
366.8 \mathrm{a} \\
788.2\end{array}$ & $\begin{array}{r}8.17 \\
10.30 \\
7.75\end{array}$ \\
\hline 4 & $\begin{array}{l}1971 \\
1972 \\
1982\end{array}$ & $\begin{array}{l}1.03 \\
0.76 \\
0.54\end{array}$ & $\begin{array}{l}3.33 \\
3.24 \\
2.21\end{array}$ & $\begin{array}{l}5.85 \mathrm{a} \\
5.43 \\
5.51\end{array}$ & $\begin{array}{l}0.31 \mathrm{a} \\
0.44 \\
0.40\end{array}$ & $\begin{array}{l}2.93 \\
2.35 \\
2.35\end{array}$ & $\begin{array}{l}0.37 \\
0.83 \\
0.62\end{array}$ & $\begin{array}{l}2.37 \\
1.90 \\
2.18\end{array}$ & $\begin{array}{l}0.884 \\
0.054 \\
0.119\end{array}$ & $\begin{array}{l}3 \\
5 \\
4\end{array}$ & $\begin{array}{c}271.7 \\
56.6 \mathrm{a} \\
204.3\end{array}$ & $\begin{array}{l}4.50 \\
7.10 \\
4.88\end{array}$ \\
\hline 5 & $\begin{array}{l}1971 \\
1972 \\
1982\end{array}$ & $\begin{array}{l}1.05 \\
2.11 \mathrm{a} \\
1.09\end{array}$ & $\begin{array}{l}3.60 \\
3.69 \\
2.64 a\end{array}$ & $\begin{array}{l}6.05 \\
6.35 \\
6.20\end{array}$ & $\begin{array}{l}0.62 \\
1.50 \\
0.78\end{array}$ & $\begin{array}{l}3.15 \\
2.76 \\
1.80\end{array}$ & $\begin{array}{l}0.73 \\
1.29 a \\
0.71\end{array}$ & $\begin{array}{l}2.64 \\
2.50 \\
1.94\end{array}$ & $\begin{array}{l}0.885 \\
1.944 \\
1.088\end{array}$ & $\begin{array}{l}3 \\
5 \\
4\end{array}$ & $\begin{array}{r}2603.6 \\
714.9 \\
2177.1\end{array}$ & $\begin{array}{l}8.00 \\
9.70 \\
7.33\end{array}$ \\
\hline 6 & $\begin{array}{l}1971 \\
1972 \\
1982\end{array}$ & $\begin{array}{l}1.39 \\
2.51 \\
1.03\end{array}$ & $\begin{array}{l}3.52 \mathrm{ab} \\
3.75 \mathrm{~b} \\
2.42 \mathrm{a}\end{array}$ & $\begin{array}{l}6.07 \mathrm{ab} \\
6.30 \mathrm{~b} \\
5.78 \mathrm{a}\end{array}$ & $\begin{array}{l}0.62 \\
1.54 \\
0.83\end{array}$ & $\begin{array}{l}3.18 \mathrm{a} \\
1.03 \\
2.76\end{array}$ & $\begin{array}{l}0.70 \mathrm{ab} \\
1.24 \mathrm{~b} \\
0.48 \mathrm{a}\end{array}$ & $\begin{array}{l}2.73 \\
2.13 \\
2.57\end{array}$ & $\begin{array}{l}0.827 \\
1.635 \\
2.584 a\end{array}$ & $\begin{array}{l}3 \\
3 \\
4\end{array}$ & $\begin{array}{r}2603.6 \\
714.9 \\
2177.1\end{array}$ & $\begin{array}{r}9.80 \mathrm{ab} \\
8.50 \mathrm{a} \\
10.80 \mathrm{~b}\end{array}$ \\
\hline
\end{tabular}

*TC = Total coliforms, PCA = Plate count agar (standard plate count), HEN = Total heterotrophic aerobic bacteria, FC = Fecal coliforms, DEN = Denitrifying bacteria, FS = Fecal streptococci, SULFR = Sulfate-reducing bacteria.

Numbers within sites with same letter or no letters indicate no significant differences between years at $\alpha=0.05$.

Data for 1971 and 1972 used from Skinner et al. (1974a and 1974b) with permission from National Research Council of Canada (Canadian Journal of Microbiology) and American Society of Agronomy (Journal of Environmental Quality).

Gannon, J.J., M.K. Busse, and J.E. Schilliner. 1983. Fecal coliform disappearance in a river impoundment. Water Res. 11:1595-1601.

Gary, H.L. 1982. Stream water quality in a small commercial campground in Colorado. J. Environ. Health. 435:5-12.

Hendricks, C.W. 1971. Increased recovery rate of Salmonellae from stream bottom sediments versus surface waters. Appl. Microbiol. 21:279-280.

Hendricks, C.W., and S.M. Morrison. 1976. Multiplication and growth of selected enteric bacteria in clear mountain stream water. Water Res. 1:567-576.

Hendry, G.S., and E.A. Leggat. 1982. Some effects of shoreline cottage development on lake bacteriological water quality. Water Res. 16:1217-1222.

Jahn, L.R. 1978. Values of riparian habitat to natural ecosystems. In: Proceedings of Symposium Strategies for Protection and Management of Floodplain Wetlands and Other Riparian Ecosystems. USDA Forest Serv. GTR-WO-150-157.

Jawson, M.D., L.F. Elliott, K.E. Saxton, and D.H. Fortier. 1982. The effects of cattle grazing on indicator bacteria in runoff from a Pacific Northwest watershed. J. Environ. Qual. 11:621-627.

Kay, D., and A. MeDonald. 1980. Reduction of coliform bacteria in two upland reservoirs: The significance of distance decay relationships. Water Res. 14:305-318.

Matson, E.A., S.G. Hornor, and J.D. Buck. 1978. Pollution indicators and other microorganisms in river sediment. J. Water Poll. Contr. Fed. 50:13-19.

McDonald, A., and D. Kay. 1981. Enteric bacterial concentrations in reservoir feeder streams: Baseflow characteristics and response to hydrograph events. Water Res. 15:961-968.

Skinner, Q.D., J.C. Adams, P.A. Rechard, and A.A. Beetle. 1974a. Enumeration of selected bacterial populations in a high mountain Watershed. Can. J. Microbiol. 20:1487-1492.

Skinner, Q.D., J.C. Adams, P.A. Rechard, and A.A. Beetle. 1974b. Effect of summer use of a mountain watershed on bacterial water quality. $J$. Environ. Qual. 3:329-335.
Skinner, Q.D., and J.C. Adams. 1977. Water quality near ski areas, Medicine Bow National Forest: A final report, WYO Project 16-516-CA. Water Resources Research Institute, University of Wyoming, Laramie . Skinner, Q.D., J.E. Speck, Jr., M. Smith, and J.C. Adams. 1984. Stream water quality as influenced by beaver within grazing systems in Wyoming. J. Range Manage. 37:142-146.

Steel, R.D., and J.H. Torrie. 1960. Principles and procedures of statistics. McGraw-Hill Book Co., Inc. New York, NY.

Stephenson, G.R., and L.V. Street. 1978. Bacterial variations in streams from a southwestern Idaho rangeland watershed. J. Environ. Qual. 7:150-157.

Stephenson, G.R., and R.C. Rychert. 1982. Bottom sediment: a reservoir of Escherichia coli in rangeland streams. J. Range Manage. 35:119-123.

Stuart, D.G., G.K. Bissonnette, T.D. Goodrich, and W.G. Walter. 1971. Effects of multiple use on water quality of high-mountain watersheds: Bacteriological investigations of mountain streams. Appl. Environ. Microbiol. 22:1048-1054.

Stuart, S.A., G.A. McFeters, J.E. Schillinger, and D.G. Stuart. 1976. Aquatic indicator bacteria in the high alpine zone. Appl. Environ. Microbiol. 31:163-167.

VanDonsel, D.J., E.E. Geldreich, and N.A. Clarke. 1967. Seasonal variations in survival of indicator bacteria in soil and their contribution to storm-water pollution. Appl. Microbiol. 15:1362-1370.

VanDonsel, D.J., and E.E. Geldreich. 1971. Relationships of Salmonellae to fecal coliforms in bottom sediments. Water Res. 5:1079-1087.

Varness, K.J., R.E. Pachs, and R.F. Lapen. 1978. Effects of dispersed recreational activities on the microbiological quality of forest surface water. Appl. Environ. Microbiol. 36:95-104.

Walter, W.G., and R.P. Botman. 1967. Microbiological and chemical studies of an open and closed watershed. J. Environ. Health. 30:157-163. 